\title{
Structure and properties of Al-Mg-Si alloys with Zr and Sc additions produced by melt spinning and twin rolling casting techniques
}

\author{
L. Lityńska-Dobrzyńska ${ }^{1 *}$, J. Dutkiewicz ${ }^{1}$, W. Maziarz ${ }^{1}$, P. Ochin ${ }^{2}$ \\ ${ }^{1}$ Institute of Metallurgy and Materials Science, Polish Academy of Sciences, 30-059 Cracow, 25, Reymonta St., Poland \\ ${ }^{2}$ Institut de Chimie et des Matériaux Paris Est, CNRS-Université Paris XII, 2-8 rue Henri Dunant, 94320 Thiais, France
}

Received 28 July 2008, received in revised form 14 October 2009, accepted 4 November 2009

\begin{abstract}
Aluminium alloys with 1 wt. $\% \mathrm{Mg}, 0.6$ wt.\% Si and 0.5 wt.\% $\mathrm{Zr}$, or 0.5 wt.\% $\mathrm{Zr}+$ 0.2 wt.\% Sc additions were cast using different techniques such as: conventional stationary mould casting, twin rolling and melt spinning. Microstructure studies have shown that a significant grain refinement down to $20 \mu \mathrm{m}$ was obtained in the alloy containing $0.5 \% \mathrm{Zr}$ $+0.2 \% \mathrm{Sc}$ cast to a copper mould due to the presence of $\mathrm{Al}_{3}(\mathrm{Zr}$, Sc) primary particles. Columnar grains near the surfaces and equiaxial ones in their central part were observed in strips obtained by the twin rolling method, while the ribbons of thickness $70-100 \mu \mathrm{m}$, cast using melt spinning, revealed equiaxial grains of an average diameter of $2-3 \mu \mathrm{m}$. The additions of Sc and Zr brought about a small increase of microhardness only in the mould cast alloys and strips while no changes in microhardness have been observed in alloys prepared using various casting techniques. The alloys produced by both unconventional casting techniques were annealed at the temperature range of $400-540^{\circ} \mathrm{C}$, which resulted in the precipitation of either $\mathrm{Al}_{3} \mathrm{Zr}$ or $\mathrm{Al}_{3}(\mathrm{Zr}, \mathrm{Sc}$ ) phases from the $\mathrm{Al}$ solid solution in the form of spherical (about $10 \mathrm{~nm}$ large) particles as well as an additional microhardness increase up to about $130 \mathrm{HV}$ for the $\mathrm{AlMg} 1 \mathrm{Si0} 6 \mathrm{Zr} 0.5 \mathrm{Sc} 0.2$ alloy.
\end{abstract}

K e y w o r d s: aluminium alloys, rapid solidification, melt spinning, microindentation, transmission electron microscopy (TEM), energy dispersive X-ray spectroscopy (EDX)

\section{Introduction}

The Al-Mg-Si alloys belong to the group of $6 \mathrm{xxx}$ alloys, which are commonly applied in the construction and motor industry. They reveal lower strength compared to the $7 \mathrm{xxx}(\mathrm{Al}-\mathrm{Zn}-\mathrm{Mg}-\mathrm{Cu})$ and $2 \mathrm{xxx}$ (Al-Cu-Mg) alloys, but their corrosion resistance is better and plasticity is very good. The investigation carried out recently has aimed at achieving higher properties of these alloys through the addition of zirconium and scandium to the 6 xxx series alloys. The advantages of such modification of composition, described in [1-4], are as follows:

- Grain refinement in as-cast alloy due to the presence of fine, primary $\mathrm{Al}_{3}(\mathrm{Zr}, \mathrm{Sc})$ particles, which act as crystallization nuclei.
- Strengthening of the alloy caused by the occurrence of the fine, matrix coherent precipitates of $\mathrm{Al}_{3}(\mathrm{Zr}, \mathrm{Sc})$ phase with $\mathrm{L}_{2}$ structure, which appear during ageing at $300-500{ }^{\circ} \mathrm{C}$.

- Retardation of the grain boundary motion during heat treatment due to the presence of the $\mathrm{Al}_{3}(\mathrm{Zr}, \mathrm{Sc})$ dispersoids, which contributes to the increase of the recrystallization temperature and creates a possibility of superplastic deformation.

The addition of the increased amount of $\mathrm{Zr}$ and $\mathrm{Sc}$ into the $\mathrm{Al}$ solid solution in order to obtain their advantageous effect on the alloy properties is possible through rapid solidification between two rotating cylinders (twin rolling) or on a spinning cylinder (melt spinning) $[5,6]$. According to the data presented in [5], the maximum extent of the solid solubility ob-

\footnotetext{
*Corresponding author: tel.: 48126374200; fax: 0126372192; e-mail address: nmlityns@imim-pan.krakow.pl
} 
Table 1. Chemical composition of examined alloys (in wt.\%)

\begin{tabular}{lccccc}
\hline Alloy & $\mathrm{Al}$ & $\mathrm{Mg}$ & $\mathrm{Si}$ & $\mathrm{Zr}$ & $\mathrm{Sc}$ \\
\hline AlMg1Si0.6 & remaining & 1 & 0.6 & - & - \\
AlMg1Si0.6Zr0.5 & remaining & 1 & 0.6 & 0.5 & - \\
AlMg1Si0.6Zr0.5Sc0.2 & remaining & 1 & 0.6 & 0.5 & 0.2 \\
\hline
\end{tabular}

tained by rapid solidification could reach 3.2 at.\% for scandium and 1.5 at. $\%$ for zirconium compared to the maximum equilibrium solid solubility, which is 0.25 at.\% and 0.083 at.\%, respectively.

The aim of the present work was to compare the microstructure of Al-Mg-Si alloys cast into a mould or prepared using twin rolling as well as melt spinning techniques and to determine the role of $\mathrm{Zr}$ and $\mathrm{Zr}+$ Sc additions at different solidification rates.

\section{Experimental}

The alloys were produced using Al-45wt.\% $\mathrm{Si}, \mathrm{Al}-$ $-10 \mathrm{wt} . \% \mathrm{Zr}, \mathrm{Al}-2 \mathrm{wt} . \% \mathrm{Sc}$ master alloys and $\mathrm{Al}$ and $\mathrm{Mg}$ of $99.9 \%$ purity. After melting, the alloys were cast into a thick-wall copper mould to ensure high cooling rate (about $100{ }^{\circ} \mathrm{C} \mathrm{s}^{-1}$ ) during solidification. The use of such a type of mould was necessary to retain $\mathrm{Sc}$ and $\mathrm{Zr}$ in the supersaturated solid solution. The obtained ingots were of the following dimensions: $150 \mathrm{~mm} \times 60 \mathrm{~mm} \times 10 \mathrm{~mm}$. The contents of $\mathrm{Mg}$ and Si (1.0 and 0.6 wt.\%, respectively) were balanced in all the investigated alloys to get an atomic $\mathrm{Mg} / \mathrm{Si}$ ratio of $2: 1$, the same as in the $\mathrm{Mg}_{2} \mathrm{Si}$ phase, which is the main strengthening phase in the $6 \mathrm{xxx}$ series alloys. The compositions of alloys are given in Table 1 .

The alloys were also cast using two other techniques: (i) casting between two rotating cylinders (twin rolling) and (ii) casting onto a spinning copper cylinder (melt spinning). The twin roll casting was performed, when the temperature of the liquid alloy achieved $875-945^{\circ} \mathrm{C}$. The alloys were cast under $0.15 \mathrm{MPa}$ pressure of helium, which ejected the liquid metal through a hole of $1.9 \mathrm{~mm}$ diameter in the bottom of the quartz nozzle between $40 \mathrm{~cm}$ diameter copper alloy cylinders, rotating at a linear rate of $v$ $=1.1 \mathrm{~m} \mathrm{~s}^{-1}$. The melt spinning was carried out under a protective helium atmosphere at linear rate of the wheel $v=22 \mathrm{~m} \mathrm{~s}^{-1}$. The pressure of the gas ejecting the molten alloy was $0.15 \mathrm{MPa}$. The melting pot made of quartz had a hole of $0.7 \mathrm{~mm}$ in diameter in the bottom. The estimated cooling rate was $10^{3}{ }^{\circ} \mathrm{C} \mathrm{s}^{-1}$ for the twin rolling and $10^{6}{ }^{\circ} \mathrm{C} \mathrm{s}^{-1}$ for melt spinning.

The structure of the cast alloys and ribbons was studied using a Leica DM IRM light microscope. Pol- ished specimens were etched with $0.5 \% \mathrm{HF}$ solution. The microstructure was observed using Philips XL30 scanning electron microscope (SEM), Philips CM 20 and Technai $\mathrm{G}^{2}$ transmission electron microscopes (TEM) equipped with EDAX energy dispersive X-ray (EDX) detectors. Thin foils were obtained with "double-jet" technique in Tenupol-5 device using an electrolyte containing $30 \%$ solution of $\mathrm{HNO}_{3}$ in methyl alcohol. The thinning was carried out at temperature $-30^{\circ} \mathrm{C}$ and voltage $15 \mathrm{~V}$. Microhardness Vickers measurements were performed using CSM-Instruments tester.

\section{Results and discussion}

\subsection{Mould cast alloys}

Light microstructures of the alloys cast into a thick-wall copper mould are shown in Fig. 1a-c. The AlMg1Si0.6 alloy had the grain size of $200-500 \mu \mathrm{m}$ with a dendritic structure consisting of the $\mathrm{Al}$ solid solution and $\mathrm{Mg}_{2} \mathrm{Si}$ phase (Fig. 1a). A partial reduction of the branching of the dendritic structure was observed in the alloy with $0.5 \mathrm{wt} . \% \mathrm{Zr}$ addition, whose grain size decreased down to about $100 \mu \mathrm{m}$ (Fig. 1b), while in the alloy with 0.5 wt. $\% \mathrm{Zr}+0.2 \mathrm{wt} . \% \mathrm{Sc}$ the refinement of grains down to about $20 \mu \mathrm{m}$ was observed together with a complete disappearance of dendritic segregation (Fig. 1c). The grain refinement resulted from the presence of a primary $\mathrm{Al}_{3}(\mathrm{Zr}, \mathrm{Sc})$ particles, which formed first during the alloy solidification and became the nuclei for the crystallization of $\mathrm{Al}$ solid solution. The example of the $\mathrm{Al}_{3}(\mathrm{Zr}, \mathrm{Sc})$ particle with a cubic morphology is shown in SEM microstructure in Fig. 1d. The EDX microanalysis confirmed that the particles located in the centre of the grain were enriched in $\mathrm{Zr}$ and $\mathrm{Sc}$, while those lying at the grain boundaries were identified mainly as $\mathrm{Mg}_{2} \mathrm{Si}$ phase. A good lattice coherence between the ordered $\mathrm{L}_{2}-\mathrm{Al}_{3}(\mathrm{Zr}, \mathrm{Sc})$ primary particles and the $\alpha(\mathrm{Al})$ matrix was the reason for the effective grain reduction and uniform grain structure $[3,7]$.

\subsection{Strips obtained by the twin roll technique}

The width of the strips produced using the twin rolling method was about $15 \mathrm{~mm}$ for the AlMg1Si0.6 and AlMg1Si0.6Zr0.5 alloys and about $10 \mathrm{~mm}$ for the AlMg1Si0.6Zr0.5Sc0.2 alloy. The strips had frayed edges due to the irregular outflow of the liquid alloy out of the nozzle. The light microstructures of the strip cross-sections are collected in Fig. 2a-c, which allowed estimating their thickness at about $0.6 \mathrm{~mm}$. The influence of the $\mathrm{Zr}$ and Sc additions for the twin roll strips was observed to be less essential than for the mould cast alloys. For all alloys a darker line 

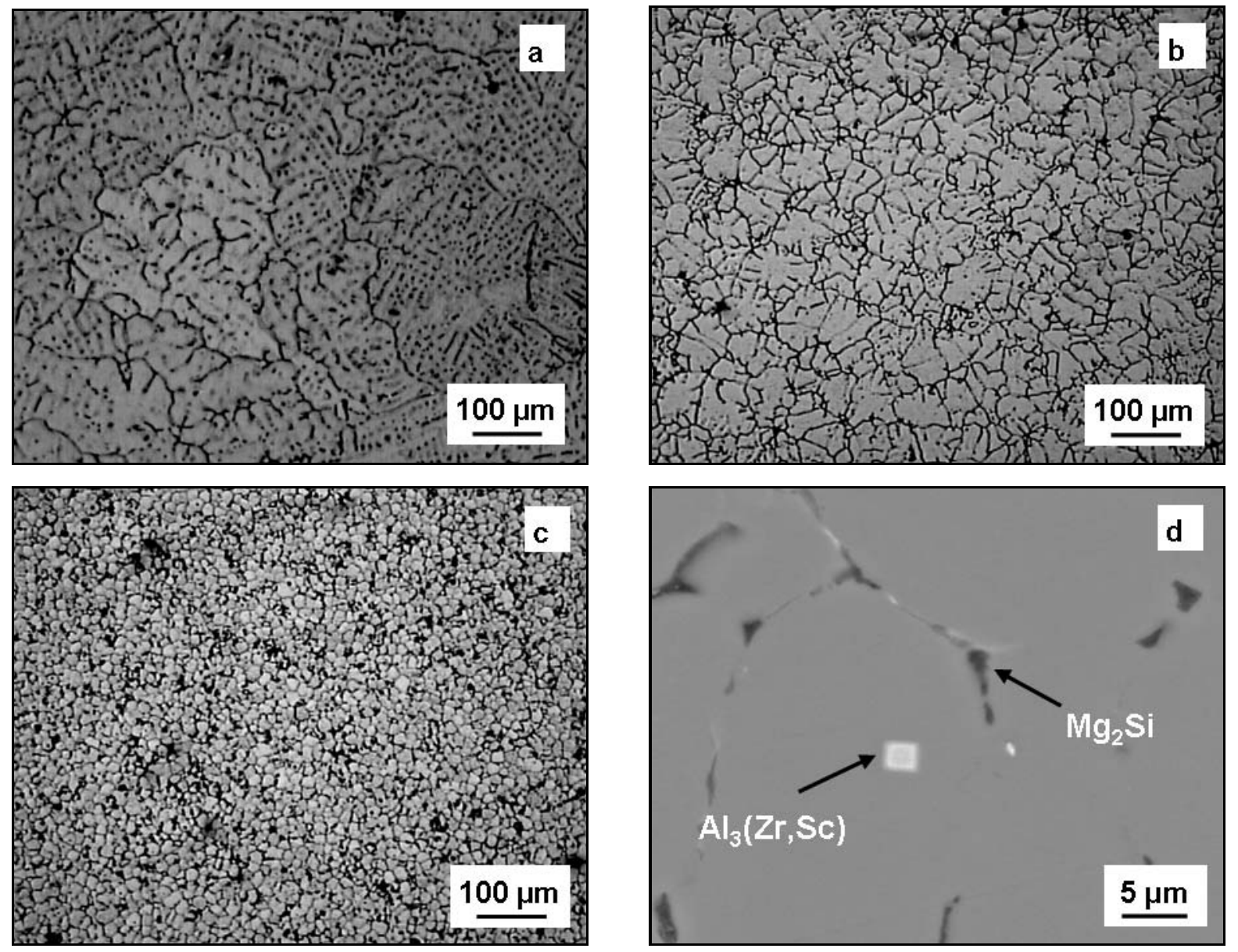

Fig. 1. Light microstructures of the alloys cast into a thick-wall copper mould: (a) AlMg1Si0.6, (b) AlMg1Si0.6Zr0.5, (c) AlMg1Si0.6Zr0.5Sc0.2; (d) SEM micrograph of $\mathrm{Al}_{3}(\mathrm{Sc}, \mathrm{Zr})$ primary particle in AlMg1Si0.6Zr0.5Sc0.2 alloy.

could be seen in the central part of the strips, which separated them into two parts corresponding to the place where two solidified layers met, and the columnar grains grew from the surface of the strip towards their centre. The equiaxial grains in the central part of the strips were visible occasionally in the AlMg1Si0.6Zr0.5 alloy and more frequently in the case of the AlMg1Si0.6Zr0.5Sc0.2 alloy (Fig. 2c). The columnar and equiaxial grains were of dendritic morphology. The columnar grains solidified first on the surface of the rotating wheels and their growth was blocked by the equiaxial ones nucleated in the melt ahead of the solidification front.

The TEM observation of thin foils obtained from the central part of the investigated strips allowed estimating an average size of the grain to be about a few $\mu \mathrm{m}$. The example of the TEM microstructure of the AlMg1Si0.6Zr0.5Sc0.2 alloy is shown in Fig. 3a. Subgrains and numerous dislocations have been observed inside the grains. The dislocation network could be seen clearly in the TEM microstructure presented in Fig. 3b. The dislocations formed as a result of deformation of the solidified alloy when it passed between the rolls. The precipitates, which appeared during solidification, were observed at the boundaries and inside the grains. One of the particles, situated in the centre of the grain, is marked by an arrow in the STEM-HAADF image in Fig. 4. Based on the results of EDX microanalysis it was established that the particles were enriched in $\mathrm{Zr}$ and Sc and consequently it became clear that it was the $\mathrm{Al}_{3}(\mathrm{Zr}, \mathrm{Sc})$ phase, which acted as nuclei for crystallization for the $\alpha(\mathrm{Al})$, similarly to the conventionally cast alloy. However, the $\mathrm{Zr}$ and $\mathrm{Sc}$ rich particles were observed also at the grain boundaries together with the $\mathrm{Mg}_{2} \mathrm{Si}$ phase and precipitates containing $\mathrm{Fe}, \mathrm{Si}$ and $\mathrm{Mg}$. The precipitates often formed aggregates. The example of such a complex particle, accompanied by the element distribution inside it, is shown in Fig. 5. In its central part, the enrichment in $\mathrm{Zr}$ (presumably $\mathrm{Al}_{3} \mathrm{Zr}$ ) was recorded, what suggested that it had been formed in the first stage of solidification and then served as nucleus for other phases, rich in $\mathrm{Mg}, \mathrm{Si}$ and Fe. It means that most of the primary particles containing $\mathrm{Zr}$ and Sc, which formed in the liquid, have been pushed away by the solidification front and did not act as grain nuclei. In the recent work [9] it was shown, that the grain size was a function of refiner addition level, solute con- 

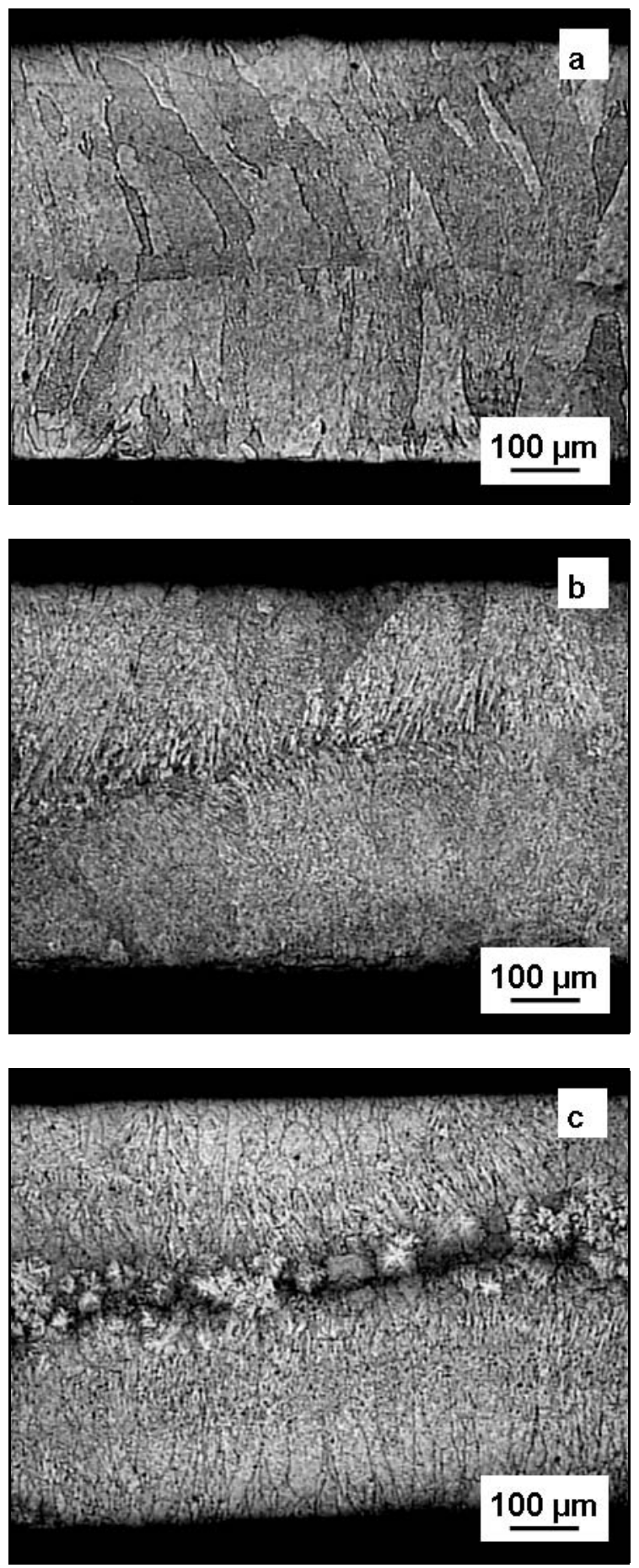

Fig. 2. Light microstructures of the strips obtained using twin rolling technique: (a) AlMg1Si0.6, (b) AlMg1Si0.6Zr0.5, (c) AlMg1Si0.6Zr0.5Sc0.2.

tent of the melt and cooling rate. It was found out, that the impingement of growing grains on inoculant particles was the major factor limiting the grain refinement efficiency. In the case of the investigated strips the cooling rate was probably so high that only part of the primary $\mathrm{Al}_{3} \mathrm{Zr}$ or $\mathrm{Al}_{3}(\mathrm{Zr}, \mathrm{Sc})$ particles contributed
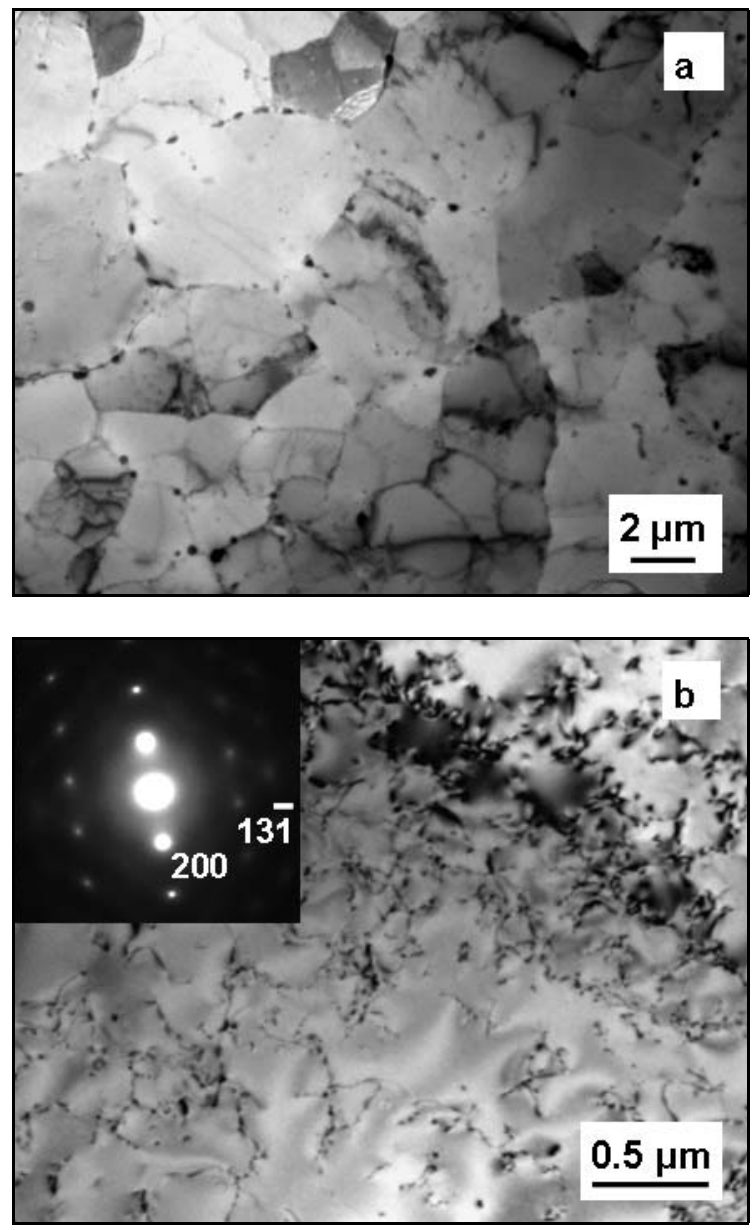

Fig. 3a,b. TEM bright field images of the twin rolling strips of the AlMg1Si0.6Zr0.5Sc0.2 alloy; in Fig. 3b, corresponding diffraction pattern is inserted - zone axis close to [013] $\alpha(\mathrm{Al})$.

to the nucleation of the equiaxial grains and most of them became inactive. The EDX results showed also that the matrix contained up to about $0.4 \mathrm{wt} . \%$ of $\mathrm{Zr}$ in the AlMg1Si0.6Zr0.5 strips and about 0.1 wt.\% of Sc and 0.3 wt.\% of $\mathrm{Zr}$ in AlMg1Si0.6Zr0.5Sc0.2 ones (the maximum value detected in both alloys), which exceeded maximum solid solubility of the elements at equilibrium conditions. Higher level of $\mathrm{Zr}$ and $\mathrm{Sc}$ atoms in aluminium solid solution leads to the increase of density of the $\mathrm{Al}_{3} \mathrm{Zr}$ or $\mathrm{Al}_{3}(\mathrm{Zr}, \mathrm{Sc})$ dispersoids formed during the subsequent heat treatment.

The strips containing $\mathrm{Sc}$ and $\mathrm{Zr}$ were annealed at $400{ }^{\circ} \mathrm{C}$ to ensure the precipitation of the $\mathrm{Al}_{3} \mathrm{Zr}$ or $\mathrm{Al}_{3}(\mathrm{Zr}, \mathrm{Sc})$ phases from the $\alpha(\mathrm{Al})$ solid solution. Simultaneously, metastable phases of composition close to $\mathrm{Mg}_{2} \mathrm{Si}$ formed [8]. After annealing at $540^{\circ} \mathrm{C}$, followed by water cooling, a complete dissolution of the $\mathrm{Mg}_{2} \mathrm{Si}$ type precipitates as well as further growth of $\mathrm{Al}_{3} \mathrm{Zr}$ or $\mathrm{Al}_{3}(\mathrm{Zr}, \mathrm{Sc})$ dispersoids were observed, which had already started at $400{ }^{\circ} \mathrm{C}$. The homogeneous distribu- 


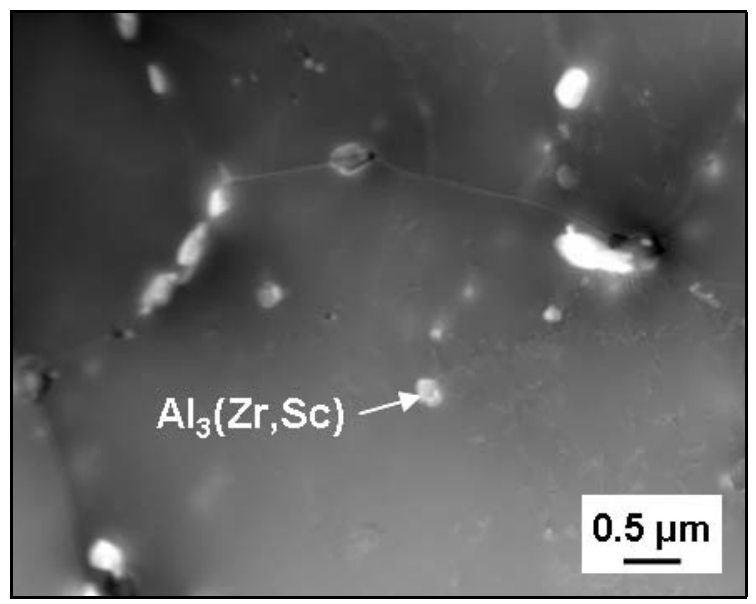

Fig. 4. STEM-HAADF image of the twin rolled strips of the AlMg1Si0.6Zr0.5Sc0.2 alloy.

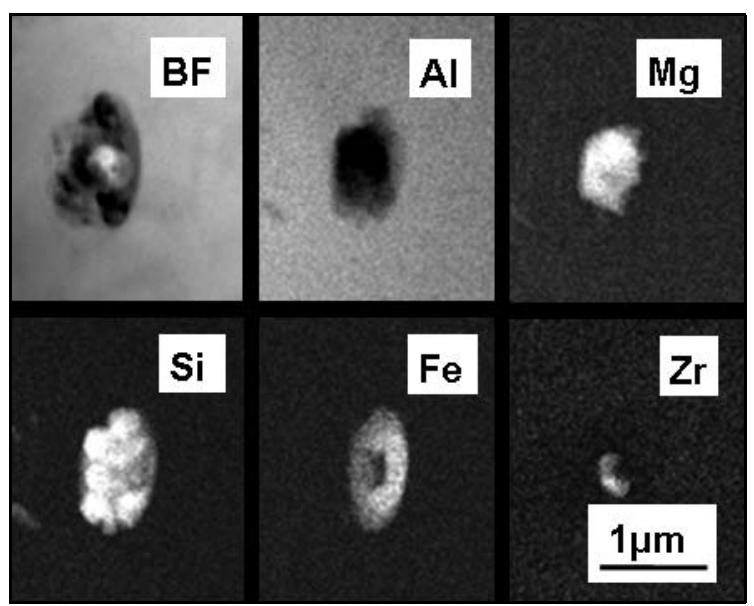

Fig. 5. TEM image of the precipitate in the AlMg1Si0.6$\mathrm{Zr} 0.5$ strip and maps of the element distribution inside the precipitate.

tion of the metastable $\mathrm{L}_{2}-\mathrm{Al}_{3} \mathrm{Zr}$ precipitates of $10 \mathrm{~nm}$ size in the AlMg1Si0.6Zr0.5 strip is shown in Fig. 6. Fine spherical $\mathrm{L}_{2}-\mathrm{Al}_{3} \mathrm{Zr}$ or $\mathrm{L}_{2}-\mathrm{Al}_{3}(\mathrm{Zr}, \mathrm{Sc})$ particles have a positive effect on the properties through increasing the hardness of the alloys, stabilizing the grain structure of the alloy and preventing recrystallization by pinning grain and sub-grain boundaries $[1,3]$.

\subsection{Melt spun ribbons}

Rapidly cooled ribbons of AlMg1Si0.6Zr0.5 and AlMg1Si0.6Zr0.5Sc0.2 alloys produced using the melt spinning technique were $3-4 \mathrm{~mm}$ wide and 70-100 $\mu \mathrm{m}$ thick. They were of good quality and homogeneous along their length. The light microstructures of cross-sections presented in Fig. 7a,b show fine-grain homogenous morphology in the whole volume of both ribbons. The average size of the equiaxial grains was

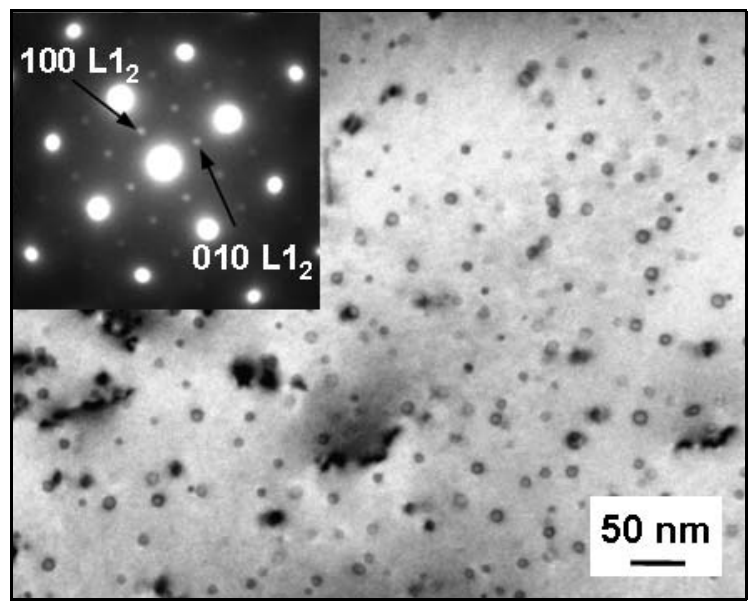

Fig. 6. TEM bright field image and corresponding diffraction pattern as an insert of the AlMg1Si0.6Zr0.5 twin rolled strip heat-treated at $400{ }^{\circ} \mathrm{C}$ for $5 \mathrm{~h}$ followed by 30 min at $540{ }^{\circ} \mathrm{C}$ and water cooling; the $\mathrm{L}_{2}-\mathrm{Al}_{3} \mathrm{Zr}$ reflections are indexed in the diffraction pattern.

estimated at $2-3 \mu \mathrm{m}$ from the TEM microstructures presented in Fig. 7c,d. Small amount of the second phase was observed at the grain boundaries. Based on EDX microanalysis it was identified mainly as the $\mathrm{Mg}_{2} \mathrm{Si}$ phase (Fig. 8). The phase also occurred inside the grains in the form of spherical precipitates. The phases enriched in $\mathrm{Fe}$ and $\mathrm{Si}$ were observed to be of similar form and size. Apart from them, elongated particles enriched in $\mathrm{Zr}$, which might be the $\mathrm{Al}_{3} \mathrm{Zr}$ phase, were also visible occasionally in the ribbons with the $\mathrm{Zr}$ addition. Contrary to the twin rolling strips, the small $\mathrm{Al}_{3} \mathrm{Zr}$ or $\mathrm{Al}_{3}(\mathrm{Zr}, \mathrm{Sc})$ particles were detected neither inside the grains nor at the grain boundaries.

Fine precipitates of the $\mathrm{Al}_{3}(\mathrm{Zr}, \mathrm{Sc})$ phase were observed in the $\mathrm{AlMg} 1 \mathrm{Si} 0.6 \mathrm{Zr} 0.5 \mathrm{Sc} 0.2$ ribbons annealed for $5 \mathrm{~h}$ at $400^{\circ} \mathrm{C}$ followed by $30 \mathrm{~min}$ at $540^{\circ} \mathrm{C}$ and cooled. Typical "coffee bean" contrast, resulting from the presence of strains in the crystallographic lattice around precipitates coherent with the matrix, was observed in the two-beam condition in the bright field TEM image close to the [001] axis of $\alpha(\mathrm{Al})$ phase (Fig. 9).

\subsection{Microhardness measurements}

Microhardness measurements were performed for the mould cast alloys and cross-sections of twin rolled strips and melt spun ribbons in an as-cast state and after heat treatment at $400^{\circ} \mathrm{C}$ for $5 \mathrm{~h}$ followed by $30 \mathrm{~min}$ at $540^{\circ} \mathrm{C}$. The measurements were carried out for the central part of the strips and the ribbons. The results, which were the average values of about ten indentations, are presented in Table 2 . The additions of $\mathrm{Zr}$ resulted in a small increase in the micro- 
Table 2. Microhardness of the mould cast alloys, twin rolling strips and melt spinning ribbons as-cast and heat-treated at $400^{\circ} \mathrm{C}$ for $5 \mathrm{~h}$ followed by $30 \mathrm{~min}$ at $540^{\circ} \mathrm{C}$

\begin{tabular}{|c|c|c|c|c|c|c|}
\hline \multirow{3}{*}{ Alloy } & \multicolumn{6}{|c|}{ Microhardness HV $0.2(\mathrm{~N})$} \\
\hline & \multicolumn{2}{|c|}{ Mould casting } & \multicolumn{2}{|c|}{ Twin rolling } & \multicolumn{2}{|c|}{ Melt spinning } \\
\hline & as-cast & heat-treated & as-cast & heat-treated & as-cast & heat-treated \\
\hline AlMg1Si0.6 & $91 \pm 3$ & $101 \pm 2$ & $89 \pm 2$ & $109 \pm 2$ & - & - \\
\hline AlMg1Si0.6Zr0.5 & $94 \pm 3$ & $119 \pm 4$ & $100 \pm 2$ & $122 \pm 2$ & $104 \pm 2$ & $128 \pm 6$ \\
\hline AlMg1Si0.6Zr0.5Sc0.2 & $105 \pm 1$ & $130 \pm 5$ & $105 \pm 3$ & $131 \pm 3$ & $104 \pm 2$ & $133 \pm 3$ \\
\hline
\end{tabular}
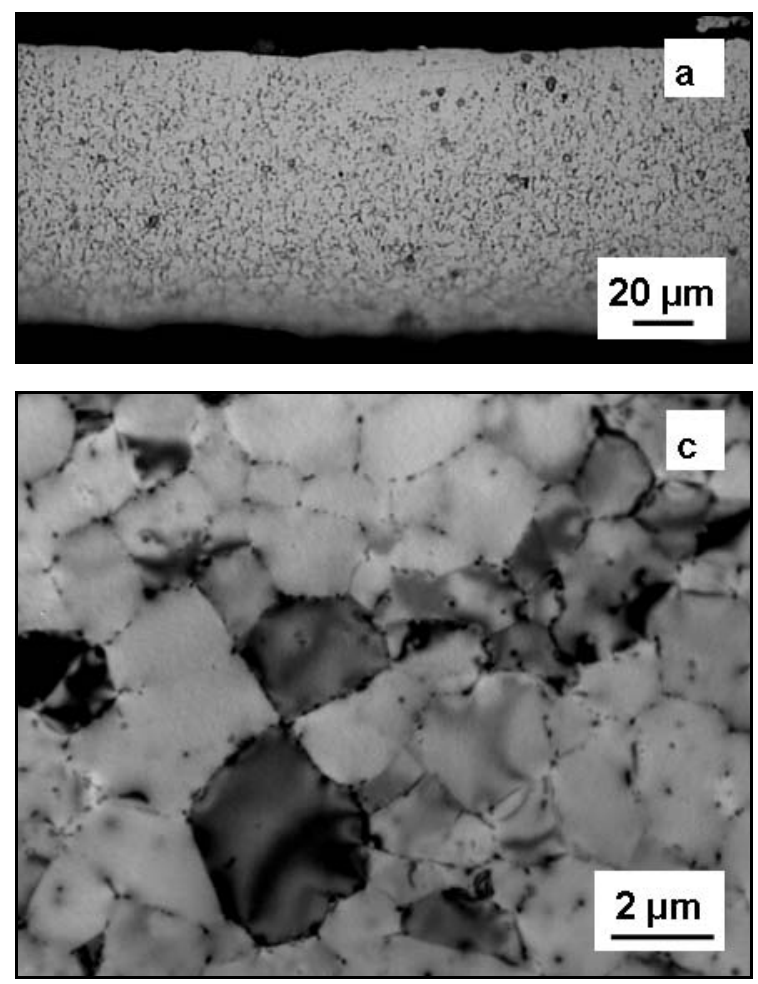
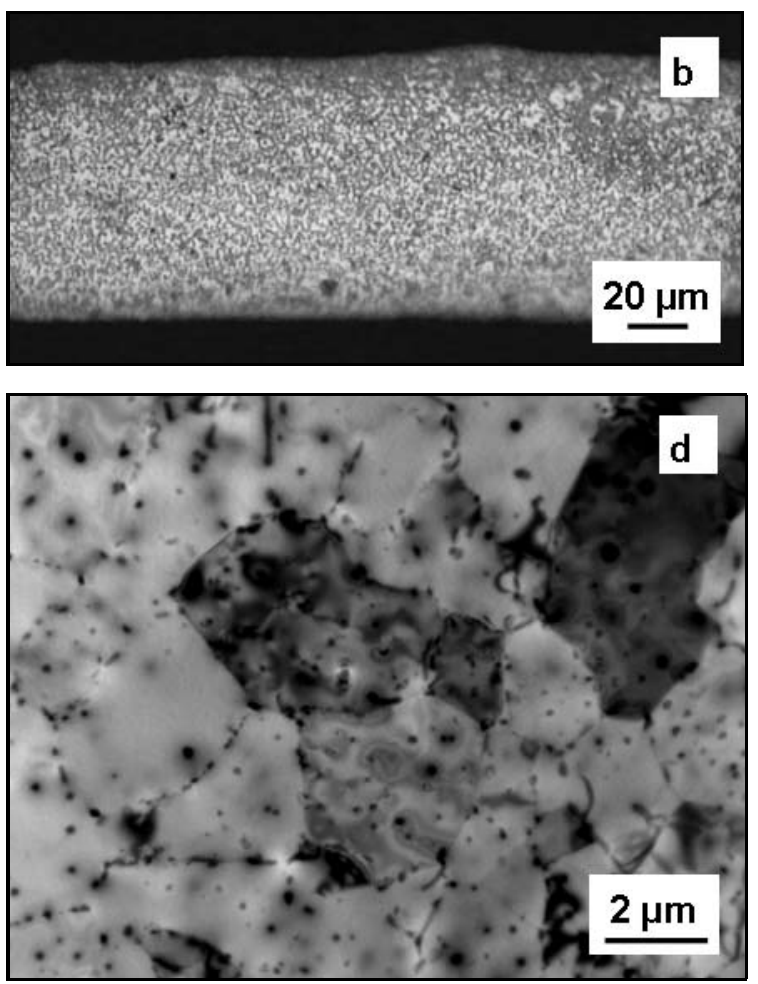

Fig. 7. Light microstructures of cross-sections of ribbons (a, b) and TEM images (c, d) of AlMg1Si0.6Zr0.5 (a, c), AlMg1Si0.6Zr0.5Sc0.2 (b, d) alloys.

hardness of mould cast alloys, strips and the ribbons for the as-cast samples. The addition of Sc caused additional hardening and the effect of the mode of casting was hardly seen, while in the case of the AlMg1Si0.6Zr0.5 alloy the microhardness increased with increasing cooling rate. Probably it was connected with the well-pronounced refinement of grain size in the Sc containing mould cast alloy. Generally, the effect of cooling rate on microhardness of as-cast alloys was not too strong, most probably due to the fact, that a decrease of grain size with cooling rate was accompanied by smaller number of precipitates. Additionally twin rolling introduced an increase of the dislocation density, due to the rolling effect. The heat treatment of the alloys caused the microhardness increase as compared to the as-cast alloys. The dis- solution of the main alloying elements ( $\mathrm{Mg}$ and $\mathrm{Si}$ ) in the $\mathrm{Al}$ solid solution and following natural ageing at room temperature (precipitation of the hardening phase $\mathrm{Mg}_{2} \mathrm{Si}$ ) led to the hardness increase in all investigated alloys. Because of the same level of $\mathrm{Mg}$ and $\mathrm{Si}$ additions in all investigated alloys, the higher increase of the microhardness for the alloys containing $\mathrm{Zr}$ and Sc was caused by the precipitation of small, coherent with the matrix $\mathrm{L}_{2}-\mathrm{Al}_{3} \mathrm{Zr}$ or $\mathrm{Al}_{3}(\mathrm{Zr}, \mathrm{Sc})$ particles.

\section{Conclusions}

1. Significant grain refinement (up to about $20 \mu \mathrm{m}$ ) was observed in the AlMg1Si0.6 alloy containing 0.5 wt. $\% \mathrm{Zr}+0.2 \mathrm{wt} . \%$ Sc cast into a copper mould 


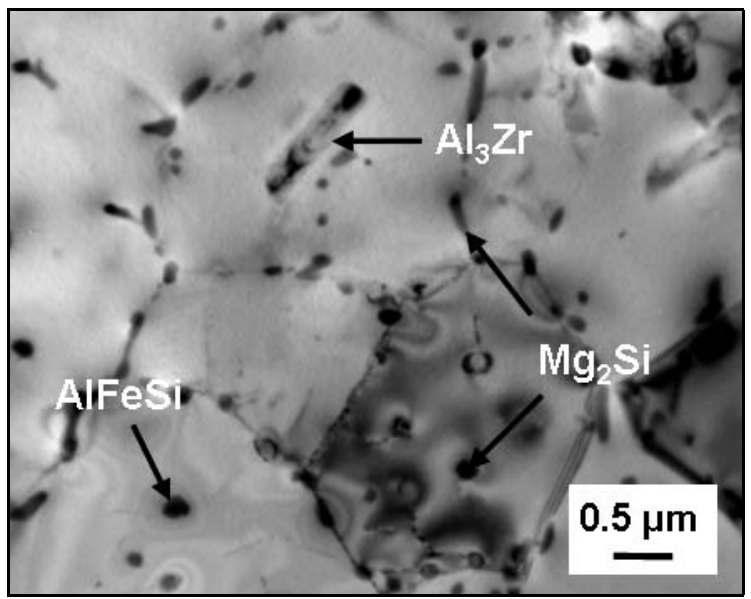

Fig. 8. TEM bright field image of the AlMg1Si0.6Zr0.5 ribbon.

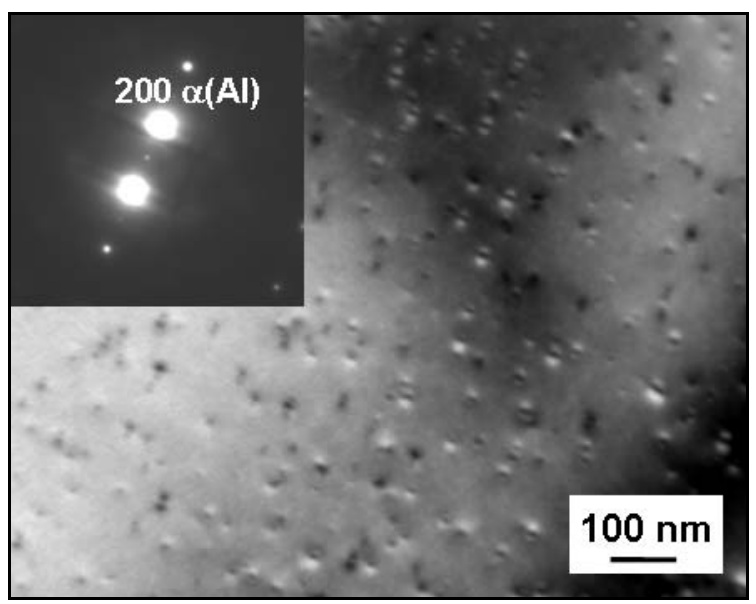

Fig. 9. Bright field TEM image accompanied by corresponding electron diffraction of the AlMg1Si0.6Zr0.5Sc0.2 ribbon heat-treated at $400^{\circ} \mathrm{C}$ for $5 \mathrm{~h}$ followed by $30 \mathrm{~min}$ at $540^{\circ} \mathrm{C}$ and water cooled - zone axis close to [001] $\alpha(\mathrm{Al})$.

as the effect of presence of fine primary $\mathrm{Al}_{3}(\mathrm{Zr}, \mathrm{Sc})$ particles.

2. The microstructure of the strips obtained by the twin rolling technique was inhomogeneous in the cross-section due to the formation of columnar grains near the surfaces and equiaxial ones in the central parts of the ribbon. The primary particles of the $\mathrm{Al}_{3} \mathrm{Zr}$ or $\mathrm{Al}_{3}(\mathrm{Zr}, \mathrm{Sc})$ phase acted as nuclei of crystallization of the $\alpha(\mathrm{Al})$ inside the equiaxial grains or formed aggregates together with the $\mathrm{Mg}_{2} \mathrm{Si}$ and $\mathrm{AlFeSi}$ phases located mainly at grain boundaries.
3. Ribbons $70-100 \mu \mathrm{m}$ thick, obtained by the melt spinning technique revealed equiaxial grains of average size $2-3 \mu \mathrm{m}$. The primary particles of the $\mathrm{Al}_{3} \mathrm{Zr}$ were only occasionally visible inside the grains.

4. The precipitation of spherical, coherent with the matrix, $\mathrm{Al}_{3} \mathrm{Zr}$ or $\mathrm{Al}_{3}(\mathrm{Zr}, \mathrm{Sc})$ phases from the $\mathrm{Al}$ solid solution was observed in twin rolled strips and melt spun ribbons annealed at $400-540^{\circ} \mathrm{C}$.

5. The additions of $\mathrm{Sc}$ and $\mathrm{Zr}$ resulted in a small increase of the microhardness of the mould cast alloys and the strips. However, the applied casting techniques did not change it significantly despite their different solidification rates. An additional increase of microhardness in the alloys annealed at $400-540{ }^{\circ} \mathrm{C}$ was attributed to the natural ageing at room temperature and precipitation of the $\mathrm{Al}_{3} \mathrm{Zr}$ or $\mathrm{Al}_{3}(\mathrm{Zr}, \mathrm{Sc})$ particles in the $\mathrm{Zr}$ and Sc containing alloys.

\section{Acknowledgements}

Partial support of the Research Project 4485/B/T02/ 2008/34 financed by the Polish Ministry of Science is gratefully acknowledged.

\section{References}

[1] RØYSET, J.-RYUM, N.: International Materials Reviews, 50, 2005, p. 19.

[2] MILMAN, Y.-LOTSKO, D. V.-SIRKO, O. I.: Mat. Sci. Forum, 331-337, 2000, p. 1107.

[3] TOROPOVA, S.-ESKIN, D. G.-KHARAKTEROVA, M. L.-DOBATKINA, T. V.: Advanced Aluminum Alloys Containing Scandium. New York, Gordon and Breach Science Publishers 1998.

[4] LITYŃSKA, L.-DUTKIEWICZ, J.: In: Proc. of International Conf. Aluminium in Transport. Krakow, Centre of Competence CentrAl 2003, p. 175, ISBN 83917129-3-1.

[5] JONES, H.: Philosophical Mag. B, 61, 1990, p. 487.

[6] LAVERNIA, E. J.-AYERS, J. D.-SRIVATSAN, T. S.: Intern. Mater. Reviews, 37, 1992, p. 1.

[7] NORMAN, A. F.-PRAGNELL, P. B.-MC EWEN, R. S.: Acta Materialia, 46, 1998, p. 5715.

[8] LITYŃSKA-DOBRZYŃSKA, L.: Archives of Metallurgy and Materials, 51, 2006, p. 555.

[9] QUESTED, T. E.-GREER, A. L.: Acta Materialia, 53,2005 , p. 4643. 